\title{
BAHASA HUMOR DALAM ACARA BOCAH NGAPA(K) YA TRANS 7 Humor Language in Impressions Bocah Ngapa(K) Ya Trans 7
}

\author{
Ferdian Achsani \\ MTs Al Mujahidin Surakarta \\ Dukuhan Rt 03/06 Banyuanyar, Banjarsari, Surakarta, 57137 \\ Pos-el: dwikurniawan219@gmail.com
}

\begin{abstract}
Abstrak: Bocah Ngapa(K) Ya merupakan salah satu tayangan humor yang hadir sebagai sarana hiburan bagi masyarakat dalam melepas penat. Sebagaimana yang kita ketahui bahwa humor pada prinsipnya merupakan tayangan yang bertujuan untuk menghibur audience agar tertawa baik melalui gerak dari para pemain, ataupun melalui bahasa yang digunakan oleh para pemain dalam berkomunikasi. Penelitian ini bertujuan untuk mendeskripsikan bahasa pembentuk humor dalam acara Bocah Ngapa(K) Ya. penelitian ini termasuk dalam jenis deskriptif kualitatif. Pengumpulan data dilakukan dengan teknik simak dan teknik catat, terhadap beberapa video Bocah Ngapa(K) Ya yang diunggah di YouTube. Hasil penelitian ini menunjukkan bahwa penciptaan bahasa humor pada tayangan Bocah Ngapa(K) Ya dapat dilihat melalui ironi, misunderstanding, permainan bunyi, perminan kata, redicule, dan repartee. Beberapa penciptaan humor melalui bahasa yang tidak ditemukan dalam humor Bocah Ngapa(K) Ya di antaranya yaitu bombast, satire, sarcasm, sexual, dan outwitting.
\end{abstract}

Kata Kunci: bahasa, tuturan, humor, Bocah Ngapa(K) Ya

\begin{abstract}
Bocah $\mathrm{Ngapa}(\mathrm{K}) \mathrm{Ya}$ is one of the humor shows that as a means of entertainment for the public in releasing fatigue. As we know that humor in principle is a show that aims to entertain the audience to laugh either through the motion of the players, or through the language used by the players in communication. This study aims to describe the language that forms humor in the event Bocah Ngapa(K) Ya. this research is included in the descriptive qualitative type. Data collection was carried out by listening and note taking techniques, to some of the Ngapa Boy (K) Yes videos uploaded on YouTube. The results of this study indicate that the creation of the language of humor in the display of Bocah $\mathrm{Ngapa}(\mathrm{K})$ $Y a$ can be seen through irony, misunderstanding, sound play, word permissions, redicule, and repartee. Some of the creation of humor through language that is not found in the humor of Bocah $\mathrm{Ngapa(K)} \mathrm{Ya} \mathrm{of} \mathrm{which} \mathrm{are} \mathrm{bombast,} \mathrm{satire,} \mathrm{sarcasm,} \mathrm{sexual,} \mathrm{and} \mathrm{outwitting.}$
\end{abstract}

Keywords: language, speech, humor, Bocah Ngapa(K) Ya

\section{PENDAHULUAN}

Humor merupakan sesuatu yang lucu yang sering digunakan sebagai obat bagi masyarakat untuk mengobati penat setelah seharian beraktivitas ataupun sekadar ingin meringankan beban pikiran untuk menghibur diri. Humor selalu diartikan sebagai sesuatu yang lucu, aneh, absurd, konyol, yang menggelikan hati, menimbulkan kejenakaan, dan kelucuan yang dapat menghibur dan mengubah suasana hati pendengar atau pembaca. Hal ini merupakan salah satu tujuan humor yaitu untuk mengundang senyum atau tawa seseorang (Suaib, Zainal, \& Liliana, 2019). Definisi humor tidak sebatas pada hal tersebut. Bisa saja tuturan dalam humor yang dilontarkan dengan maksud menghibur, terkadang tidak ter- 
kesan lucu bagi audience. Segala tuturan yang menimbulkan tawa bagi pendengar dapat dikatakan sebagai bentuk humor, sehingga humor dapat dikatakan berhasil apabila penutur dapat membangkitkan tawa audience. Humor dapat terjadi dalam segala bidang, baik itu verbal maupun nonverbal. Humor verbal menggunakan bahasa lisan, dan sering dijumpai misalnya dalam acara lawak, sedangkan humor non-verbal sering dijumpai saat ini dalam media tulis, misalnya meme.

Pemanfaatan humor tidak hanya digunakan oleh sebagian pembawa acara ataupun pelawak untuk mendatangkan pundi-pundi penghasilan, tetapi humor juga dapat digunakan sebagai refreshing dalam kegiatan-kegiatan tertentu. Misalnya, pada kegiatan pembelajaran, pemanfaatan humor berperan penting untuk mendekatkan diri antara guru dan siswa atau dosen dan mahasiswa. Siswa ataupun mahasiswa lebih menyukai guru ataupun dosen yang memiliki selera humor dalam mengajar daripada guru yang terlalu serius dalam pembelajaran. Bahkan humor juga menjadi cara efektif selama proses pembelajaran berlangsung. Sebagaimana yang diungkapkan oleh Jatiyasa (2019) bahwa humor sangat efektif dalam kegiatan pembelajaran. Pembelajaran dengan memanfaatkan humor membantu mendekatkan siswa dengan guru maupun mahasiswa dengan dosen.

Bukan hanya pada kegiatan pembelajaran, tetapi humor juga bermanfaat dalam kegiatan ceramah keagamaan. Misalnya saja masyarakat pernah dibuat heboh dengan kemunculan Ustaz Maulana yang berceramah dengan lebih menekankan pada sisi humor (Hilmi, 2018). Meskipun demikian, Ustaz Maulana juga tidak terlepas untuk mengedepankan materi ceramah yang dibawakannya. Humor yang sengaja dibuat oleh Ustaz Maulana tersebut bertujuan untuk menarik minat masyarakat dan mempermudah meyampaikan pesan kepada pendengar. Pemanfaatan humor yang digunakan baik dalam pembelajaran maupun ceramah keagamaan dengan tujuan untuk memupuk rasa persaudaraan dan keakraban antarkelompok (Hasanuddin, 2019).

Isi tuturan humor yang sangat beragam dan multi fungsi menjadikan humor menjadi bahan utama untuk menarik minat masyarakat. Misalnya saja humor dapat digunakan sebagai media kritik (anekdot), bisa juga digunakan sebagai sarana ungkapan perasaan (ngengombal), dll. Hal yang menarik dari lawak atau humor yaitu penggunaan diksi konotatif, metaphor, pelesetan kata dan homonim atau kepolisemian kata untuk menghadirkan glagat tawa pendengar. Hal ini sering kali kita dengar dalam acara-acara lawak seperti Opera Van Java (OVJ), Indonesia Lawak Klub (ILK), dll. Bahkan diksi konotatif, metaphor dan plesetan kata tersebut sudah menjadi bagian ciri khas dari para komedian. Misalnya, kita sering mendengar pembawa acara sekaligus komedian kondang Tukul Arwana yang sering memelesetkan kata 'pertinyiinnyi' dari kata 'pertanyaannya'. Hal ini sengaja dilakukan Tukul guna menarik perhatian masyarakat dan audience agar ikut tertawa dan mengubah suasana hati.

Penelitian ini akan mendeskripsikan bentuk penciptaan humor pada tayangan Bocah Ngapa (K) Ya Ya. Bocah Ngapa (K) Ya Ya merupakan salah satu tayangan yang selalu menghibur masyarakat lewat tingkah laku yang konyol dan menggelitik. Tayangan yang semula bernama Polapike yang diunggah di akun jejaring sosial YouTube itu kini ditayangkan oleh Trans 7 dengan balutan humor yang lebih menggelitik. Bocah Ngapa (K) Ya merupakan salah satu acara komedi 
yang ditayangkan di stasiun TV swasta Trans 7. Setelah sukses dengan tayangan humor OVJ yang membesarkan nama Parto, Sule, Nunung, Aziz gagap, dll., Trans 7 kembali membesarkan nama anak-anak yang menjadi pemeran dalam tayangan tersebut. Azkal, Ilham, dan Fadli merupakan tiga sekawan Dengan dibantu oleh beberapa pemeran seperti Pak RT, Bu guru, Mbak Tyas dan Ucup, menjadikan tayangan ini semakin diminati oleh masyarakat sebagai tayangan untuk penghibur diri.

Acara ini ditayangkan setiap Sabtu dan Minggu pukul 17.00-17.30 WIB. Hal yang unik dan menarik dari acara humor tersebut adalah penggunaan bahasa Jawa logat ngapak yang digunakan untuk berkomunikasi antarpemain menjadikan daya tarik tersendiri. Pasalnya bahasa Jawa logat ngapak merupakan bahasa Jawa tertua dan unik serta memiliki ciri khas tersendiri (Widyaningsih, 2014). Bahasa Jawa logat ngapak adalah bahasa Jawadwipa yang merupakan bahasa jawa murni. Keunikan tersebut dapat dilihat seperti masyarakat Banyumas yang ketika bicara tidak mengenal rasa ewuh pekewuh (Widyaningsih, 2014). Hal ini dikarenakan bahasa Jawa logat Ngapak merupakan bahasa yang apa adanya ketika berbicara, tanpa mengenal status social. Keunikan lain juga terlihat dari pola pengucapan bahasa Ngapak yang terkenal medhok, sehingga terlihat kuno. Dalam bekomuniasi keunikan juga muncul dari beberapa pengucapan seperti pengucapan vocal " $a, i, u, e, o$ " yang tetap dibaca jelas tidak seperti bahasa Jawa pada umumnya, seperti voal "a" yang dibaca "o". Keunikan dan ciri khas yang ditampilkan tersebut menjadikan setiap penutur yang menggunakan bahasa logat ini memiliki selera humor yang berkesan. Dengan demikian pemilihan bahasa ngapak sebagai bahasa pengantar dalam acara humor ini turut mempengaruhi humor yang disampaikan oleh setiap pemain. Di samping itu, pemilihan bahasa ngapak ini juga berdampak pada pelestarian bahasa daerah agar bahasa Jawa logat Ngapak masih tetap bertahan dan eksis.

Pemunculan humor melalui komunikasi bahasa yang digunakan dalam acara tersebut menjadikan peneliti tertarik untuk menelitinya. Pasalnya, Humor juga merupakan salah satu fungsi bahasa. Sebagaimana yang diungkapkan oleh Saddhono (2009) bahwa fungsi bahasa imajinatif salah satunya berfungsi untuk membacakan lelucon. Lelucon (hasil lawakan) yang dihasilkan oleh bahasa sangat variatif dan beragam. Melalui bahasa, humor dapat berbentuk teka-teki, dialog-dialog ataupun gombalan (Aisyah, 2018). Selain itu, dalam penelitian yang dilakukan oleh Sukardi, Sumarlam, \& Sri (2018) menyatakan bahwa humor dapat diciptakan melalui homonimi kata. Terkadang penutur mengucapkan sebuah kata yang memiliki makna tersendiri. Tuturan penutur tersebut ditanggapi oleh lawan tutur dengan membalikkan makna dari kata yang memiliki bunyi dan pengucapan yang sama, tetapi berbeda makna. Perbedaan makna yang disampaikan oleh lawan tutur juga menyimpan makna konotatif yang memiliki berbagai tujuan seperti menyindir, menyinggung, dll.

Selain melalui homonimi kata, Arnita, Supriyadi, \& Ansori (2019) menyatakan bahwa stetegi penciptaan humor juga dapat dilakukan melalui teknik pelanggaran prinsip kesantunan berbahasa. Pelanggaran prinsip kesantunan berbahasa yang diucapkan oleh penutur untuk menciptakan humor lebih dominan menjatuhkan atau menjelekkan lawan tutur untuk menciptakan sebuah lelucon. Hal ini sering kali terlihat dari beberapa tayangan humor yang menun- 
jukkan bahwa penggunaan bahasa yang menyimpang dari prinsip kesantunan digunakan dengan tujuan untuk menciptakan tuturan humor. Berger (dalam Anastasya, 2013) menyebutkan 11 teknik atau strategi penciptaan humor melalui bahasa di antaranya: Bombast (muluk-muluk dalam bertutur kata), Infantilism (permainan bunyi kata), Irony (perbedaan makna tuturan), Misunderstanding (salah penafsiran), Pun (permainan kata), Repartee (mengolok), Ridicule (membuat orang bodoh), Sarcasm (sarkasme), Satire (mempermalukan atau menjatuhkan orang lain), Sexual Allusion (berhubungan dengan hal-hal seksual), Outwitting (mengalah kepintaran). Sebelas poin tersebut merupakan strategi penciptaan humor melalui bahasa. Dalam penelitian ini, sebelas poin tersebut akan digunakan sebagai alat atau pisau analisis dalam penelitian ini, untuk menjawab strategi penciptaan humor dalam tayangan Bocah Ngapa (K) Ya.

Penelitian yang relevan dengan penelitian ini dilakukan oleh Budiyanto (2009). Dalam penelitian yang berjudul Penyimpangan Implikatur Percakapan dalam Humor-Humor Gus Dur, tersebut menyimpulkan bahwa penciptaan humor digunakan melalui teknik penyimpangan prinsip kerjasama. Prinsip kerjasama yang merupakan suatu prinsip yang harus dipatuhi baik oleh penutur maupun lawan tutur agar komunikasi dapat berjalan dengan lancar tersebut dalam humor Gus Dur dilanggar untuk menciptakan sebuah humor. Bukan hanya prinsip kerjasama, tetapi dalam humor Gus Dur juga menggunakan teknik kesantunan berbahasa untuk menciptakan sebuah lelucon.

Persamaan penelitian ini dengan penelitian tersebut adalah sama-sama mengkaji teknik penciptaan humor. Perbedaannya terletak pada kajian dan objek yang digunakan. Dalam penelitian tersebut, penciptaan humor dijawab melalui teori pelanggaran prinsip kerjasama dan prinsip kesantunan berbahasa. Berbeda dengan penelitian tersebut pada penelitian ini penciptaan humor menggunakan teori Barger yang menyebutkan bahwa penciptaan humor melalui bahasa diklasifikasikan menjadi sebelas bagian. Objek penelitian dengan penelitian sebelumnya juga berbeda. Pada penelitian sebelumnya, percakapan humor Gus Dur digunakan sebagai objek penelitian, sedangkan pada penelitian ini tayangan humor Bocah Ngapa (K) Ya digunakan sebagai objek penelitian.

Penelitian yang dilakukan oleh Rohmadi (2010) dalam penelitian berjudul Strategi Penciptaan Humor dengan Pemanfaatan Aspek-Aspek Kebahasaan juga dapat dikatakan relevan dengan penelitian ini. Penelitian tersebut menyimpulkan bahwa pemanfaatan humor dapat menggunakan kata-kata, gambar, tulisan, dan permainan bunyi. Persamaan dengan penelitian tersebut adalah sama-sama mengkaji teknik penciptaan humor dari segi kebahasaan. Perbedaan hanya terletak pada objek kajian yang diteliti. Pada penelitian sebelumnya, objek penelitian difokuskan pada humor yang terdapat pada media cetak, radio, televisi, ataupun media lainnya, sedangkan pada penelitian ini objek penelitian difokuskan pada tayangan humor Bocah Nagapa (K).

Penelitian yang dilakukan oleh Utami (2018) yang mengkaji bahasa humor dalam acara Stand Up Comedy juga dapat dikatakan relevan dengan penelitian ini. dalam penelitian yang berjudul Strategi Humor pada Acara Stand Up Comedy tersebut menyimpulkan bahwa pemanfaatan bahasa yang digunakan sebagai penciptaan humor, yaitu menggunakan strategi pragmatik seperti praanggapan, pelanggaran maksim, dan implikatur, sedangkan melalui strategi kebahasaan 
ditemukan seperti omong kosong, ejekan, ironi, dan kesalahpahaman. Persamaan dengan penelitian tersebut adalah mengkaji bahasa humor pada tuturan lisan. Perbedaan hanya terletak pada objek penelitain, yaitu antara Stand Up Comedy dan Bocah Ngapa (K), serta teori yang digunakan untuk menjawab penelitian. Dari penelitian yang relevan tersebut, penelitian ini akan mendeskripsikan bentuk strategi humor dalam tayangan Bocah $\mathrm{Ngapa} \mathrm{(K)} \mathrm{Ya.}$

\section{METODE PENELITIAN}

Penelitian ini termasuk dalam jenis deskriptif kualitatf. Deskriptif kualitatif merupakan metode penelitian yang menguraikan fenomena yang berupa kata-kata, bukan melalui perhitungan statistik. Metode yang digunakan dalam pengumpulan data menggunakan teknik simak dan teknik deskriptif. Teknik simak adalah teknik yang digunakan untuk memperoleh data dengan menyimak penggunaan bahasa. Istilah menyimak tidak hanya berkaitan dengan penggunaan bahasa secara lisan, tetapi juga penggunaan bahasa secara tertulis. Pemerolehan data pada penelitian ini dilakukan dengan cara menyimak penggunaan bahasa lisan yang digunakan oleh para pemain dalam tayangan Bocah Ngapa (K) Ya. Dalam hal ini peneliti tidak terlibat dalam komunikasi dan hanya menyimak penggunaan bahasa yang menimbulkan humor dalam beberapa video yang dikaji atau dianalisis. Peneliti menyimak percakapan yang menjadi objek penelitian kemudian mentranskipkan hasil percakapan dalam bentuk tulisan yang menggunakan bahasa Idonesia. Dari hal tersebut, maka pengumpulan data dilakukan dengan menggunakan teknik simak dan catat.

\section{PEMBAHASAN}

\section{Ironi}

Ironi dapat dikatakan sebagai bentuk penyelewengan makna kata yang dilakukan baik oleh penutur maupun mitra tutur. Ironi dapat dikatakan sebagai bentuk gaya bahasa yang menyatakan makna yang bertentangan dengan makna sesungguhnya. Penciptaan ironi dalam humor juga tidak terlepas dari homonimi kata. Hal ini dapat dilihat dari bentuk penciptaan humor pada tayangan Bocah $\mathrm{Ngapa} \mathrm{(K)} \mathrm{Ya}$ yang memanfaatkan pelafalan yang sama dengan arti dan makan yang berbeda. Beberapa temuan data tersebut dapat dilihat sebagai berukit.

Data 1

Azkal : Sayur apa Pak RT

Pak RT : Ini kayaknya sayur kemarin. Basi kayak gini.

Azkal : Apa iya ham, itu sayur kemarin?

Ilham : Iya itu sayur kemarin.

Fadli : Gimana sih Ham, sayur basi dikasih ke Pak RT.

Ilham : Kan tadi Pak RT ngomong, minta dibawain sayur asam. Lah saya bawain sayur kemarin kan rasanya asem. Kalau gak percaya cicipi saja.

Pak RT : Aku pinginnya sayur asam. Bukan sayur basi, yang rasanya asem.

Konteks tuturan tersebut terjadi ketika Pak RT meminta Ilham untuk dibuatkan sayur asam. Sayur asam di sini merupakan sayur yang berbahan dasar dari asam dengan racikan isi bermacam-macam sayur. Namun sayangnya Ilham 
mengira bahwa sayur asam yang dimaksudkan oleh Pak RT adalah sayur asam yang sudah basi. Dengan ekspresi yang sedikit jengkel, Pak RT menjelaskan maksudnya tersebut kepada Ilham, dan ditanggapi dengan nyengir oleh Ilham. Ironi di sini dapat dilihat dari kata sayur asam, yang dimaksudkan oleh penutur adalah sayur yang berbahan dasar dari asam tetapi lawan tutur mengira sayur asam sebagai sayur yang sudah basi. Dalam humor tersebut kesalahan pahaman melalui homonimi sengaja dibuat untuk mengundang tawa dari penonton. Meskipun Ilham sebagai lawan tutur mengetahui bahwa yang dimaksud sayur asam yaitu sayur yang berbahan dasar asam.

Data 2

Ilham : Tulang punggung $\mathrm{Bu}$

Bu guru : Iya betul. Fungsinya apa, Ham?

Ilham : Fungsinya nyari duit, Bu.

Bu guru : Kok nyari duit ham?

Ilham : Iya Bu, kan tulang punggung menghidupi keluarga.

Bu guru : Bukan tulang punggung keluarga ham. Maksudnya tulang yang ada dalam tubuh manusia.

Tuturan tersebut juga termasuk dalam jenis humor melalui ironi. Tuturan tersebut terjadi ketika Bu guru tengah menjelaskan materi tentang fungsi tulang di kelas. Bu guru mencoba berinteraksi dengan siswa, yaitu dengan bertanya kepada Ilham tentang fungsi tulang punggung. Jawaban yang diberikan oleh Ilham yaitu tulang punggung sebagai orang yang bekerja mencari nafkah bagi keluarga. Hal tersebut sesuai dengan makna ungkapan tulang punggung. Akan tetapi jawaban yang disampaikan oleh Ilham tidak sesuai dengan keinginan $\mathrm{Bu}$ guru. Jawaban yang diminta di sini adalah Ilham dapat menyampaikan salah satu fungsi tulang punggung yang salah satunya untuk menopang tubuh manusia ataupun yang lainnya, bukan untuk mencari nafkah.

Data 3

Ilham : Nah, ini Pak RT. Lik, Pak RT mau milih.

Penjual : Silahkan nPak RT, dipilih. Ada yang bunga-bunga. Ini ada yang jin. Ini polkadot, bahanya lumayan. dingin.

Pak RT : Sebentar nanti dulu. Aku itu mau cari bawahan.

Ilham : Iya Pak RT . Ini kan celana. Celana kan bawahan. Kalau atasan itu, baju, kaos.

Pak RT : Oalah ham. Maksudnya bukan itu. Maksudnya aku cari bawahan itu cari asisten. Biar bisa bantu Melayani warga. Gimana sih?

Penciptaan humor melalui ironi yang sengaja dibuat juga dapat dilihat dalam dialog tersebut. Pada dialog tersebut terlihat jelas bahwa kata bawahan menjadi homonimi yang sengaja dibuat untuk menciptakan humor. Konteks tuturan tersebut terjadi ketika Pak RT meminta Ilham untuk mencarikan bawahan. Bawahan yang dimaksudkan oleh Pak RT adalah orang yang bisa dipimpin untuk dapat membantu melayani kebutuhan warga. Tetapi Ilham justru malah mengajak Pak RT untuk menemui pedagang yang menjual bawahan (celana pendek). Dari tuturan yang memanfaatkan homonimi bawahan itu menimbulkan humor. 


\section{Misunderstanding (Salah Penafsiran)}

Misunderstanding atau salah penafsiran merupakan salah satu bentuk penciptaan humor yang dilakukan oleh penutur melalui bentuk kesalahpalahaman dengan menafsirkan makna yang berbeda dengan makna aslinya. Salah penafsiran juga termasuk dalam permainan bahasa selain permainan bunyi dan kata. Plesetan bahasa dengan teknik salah paham dilakukan oleh penutur dengan memelesetkan makna kata dari makna yang sesungguhnya, yaitu dengan melakukan salah tangkap dari maksud yang sebenarnya. Dengan demikian penciptaan humor melalui teknik salah paham dapat dikatakan sama dengan ironi, hanya terletak bahwa pada ironi hanya sekedar memelesetkan makna yang memiliki pola ucapan dan tulisan yang sama, sedangkan pada teknik salah paham dilakukan dengan melakukan tindakan yang berbeda dengan makna yang sebenarnya. Beberapa temuan data yang menunjukkan strategi penciptaan humor dalam kesalahpaahman dapat dilihat dalam beberapa kutipan data berikut ini.

Data 4

Azkal : Kaya tukang parkir saja kamu jam.

Ilham : Lah iya, dua ribu, pak ustaz.

Pak ustaz: Lha gimana sih? Kamu malah minta uang parkir?

Ilham : Kan kata pas uztad, kita harus mencontoh tukang parkir.

Tukang parkir merupakan orang yang bekerja untuk menjaga sepeda motor ataupun mobil. Tukang parkir bertugas untuk menjaga kendaraan yang dititipkan kepadanya. Dalam kutipan di atas, pak ustaz mengajarkan kepada santrisantri untuk belajar dari tukang parkir. Belajar dari tukang parkir merupakan suatu ungkapan bahwa segala sesuatu yang dimiliki oleh manusia di dunia ini hanyalah titipan. Suatu saat pasti akan diambil oleh yang punya, seperti halnya kendaraan yang dititipkan kepada tukang parkir. Akan tetapi nasihat yang disampaikan oleh pak ustaz tersebut disalah artikan oleh Ilham dengan bertindak seperti tukang parker. Ilham mengarahkan pak ustaz yang tengah bersepeda. Dengan bertindak selayaknya tukang parkir tersebut, Ilham telah menciptakan bentuk humor dengan melakukan perubahan makna terhadap makna ungkapan yang dimaksudkan oleh pak ustaz.

Data 5

Fadli : Ham, gimana sih diajak ngomong baik, baik terus?

Ilham : Heh gimana sih. Kan kemarin aku sudah bilang. Aku akan berkata baik. Nah kata pak ustaz kan, ingat? Haruslah berkata baik

Azkal : Tapi maksudnya bukan kaya gitu, Ilham.

Ilham : Baik

Konteks Tuturan tersebut terjadi ketika Fadli dan Azkal mengajak Ilham ngobrol tetapi Ilham justru menanggapinya dengan menjawab mengucapkan kata 'baik'. Dalam kontreks tuturan tersebut dijelaskan oleh pak ustaz bahwa berkata baik di sini diartikan bahwa dalam bertuturkata harus selalu santun dan sopan, agar tidak melukai perasaan orang lain dan selalu merasa rendah diri. Tetapi berkata baik di sini diartikan berlainan oleh Ilham, sehingga tuturan yang disampaikan oleh Ilham tersebut menciptakan bentuk humor yang membuat jengkel lawan tuturnya. Hal ini dilakukan oleh Ilham dengan memelesetkan makna 
ungkapan berkata baik sesuai dengan yang dimaksudkan oleh pak ustaz.

Data 6

Pak RT : Pakai lidah, apa bisa?

Ilham : Bisa Pak RT. Coba aja.

Pak RT : Gak bisa Ham, siapa yang bilang bisa?

Ilham : Kata pak ustaz ada yang lebih tajam dari pedang yaitu lidah. Tapi kok gak bisa ya?

Pak RT : Bukan kaya gitu maksudnya, Ham. Padahal sudah aku jilat-jilat.

Konteks Tuturan tersebut terjadi ketika sepeda yang dikendarai oleh Fadli terjirat tali. Pak RT mencoba untuk membantu Fadli dengan memotong menggunakan gunting. Tetapi gunting yang digunakan oleh Pak RT tidak mempan untuk menggunting tali tersebut. Ilham pun menyarankan kepada Pak RT untuk menggunakan lidah. Perintah yang dilakukan oleh Ilham tersebut menciptakan humor dengan melesetkan makna tajam lidah daripada pedang. Ungkapan peribahasa yang memiliki arti bahwa perkataan yang keluar dari mulut seseorang dapat menyakiti hati orang lain tersebut diartikan oleh Ilham selayaknya benda tajam yang mampu memotong tali.

\section{Permainan Bunyi}

Permainan bunyi bahasa merupakan salah satu bentuk penciptaan humor yang dilakukan dengan cara memelesetkan penggunaan huruf vokal dan konsonan dalam suatu kata yang menyebabkan pergeseran bunyi bahasa. Permainan bunyi bahasa dapat terjadi baik secara disengaja maupun tidak disengaja. Permainan bunyi bahasa yang dilakukan secara tidak disengaja terjadi karena kesalahan ucap yang dilakukan oleh si penutur. Sedangkan permainan bunyi bahasa yang dilakukan secara sengaja terjadi karena penutur ingin mengubah suasana formal menjadi non-formal ataupun hanya sekedar untuk menciptakan suasana santai. Permainan bunyi bahasa dapat terjadi melalui penambahan, pengurangan maupun perubahan huruf vokal maupun konsonan. Beberapa temuan data pada strategi humor permainan bunyi adalah sebagai berikut.

Data 7

Fadli : Iya Ham orang kalau bangunannya siang, nanti rejekinya dipatok ayam.

Ilham : Gak mungkin Az, Fad aku udah atiputati.

Fadli Azkal : Antisipasi, ham.

Azkal : Antisipasi apa sih ham?

Ilham : Itu lihat, ayamku sudah aku kandangi. Nggak bakal matok rejeki ku.

Kutipan dialog percakapan tersebut termasuk dalam humor permainan bunyi bahasa. Hal ini dapat dilihat pada tuturan yang disampaikan oleh Ilham pada kata atiputati. Kata atiputati tersebut merupakan permainan bunyi bahasa dari kata antisipasi yang kemudian mengalami penghilangan fonem $/ \mathrm{n} /$ dan mengalami perubahan kata /sip/ dengan kata put, serta perubahan fonem /s/ menjadi /t/. Selain permainan bunyi atiputati tersebut, pada kutipan dialog tersebut juga terdapat penciptaan humor melalui perubahan makna ungkapan. Hal ini dapat dili- 
hat pada ungkapan rezeki dipatok ayam. Sebagian orang meyakini bahwa orang yang bangunnya kesiangan maka rezekinya akan dipatok ayam. Perumpamaan yang demikian merupakan sebuah motivasi bagi manusia agar bangun lebih pagi dan bergegas untuk beraktivitas untuk mencari rezeki agar tidak didahului oleh ayam. Penciptaan humor melalui ungkapan tersebut dilakukan oleh Ilham dengan mengatakan bahwa ayam yang dimilikinya sudah dikurung sehingga tidak mungkin akan mematok rezekinya.

Data 8

$\begin{array}{ll}\text { Ilham } & \text { : Memang pada bawa mainan pistol apa AZ, fad? } \\ \text { Azkal Fadli } & \text { : Gak bawa } \\ \text { Ilham } & \text { : Terus bagaimana main tembak-tembakan kalau gak bawa } \\ & \text { mainan pistol? } \\ \text { Azkal Fadli } & \text { : Tebak-tebakan ham bukan tembak-tembakan. }\end{array}$

Konteks Tuturan tersebut terjadi ketika Fadli Azkal dan Ilham tengah berada di sungai. Azkal mengajak Ilham dan Fadli untuk bermain tebak-tebakan. Penciptaan humor terjadi pada tuturan tersebut dengan memainkan bunyi tebak-tebakan menjadi tembak-tembakan. Kedua kata reduplikasi atau perulangan kata tersebut memang memiliki bunyi yang hampir sama. Perbedaan dari kedua kata tersebut hanya terdapat pada fonem /m/ pada kata tembak-tembakan. Dengan menghilangkan bunyi fonem /m/ pada kata tembak-tembakan, Ilham menciptakan humor melalui permainan bunyi bahasa menjadi kata tebaktebakan.

Data 9
Pembeli
: Ini masukkan ke plastik
Azkal
Fadli
: Mas, kan kamu bisa masukin ke plastiknya sendiri.
Pembeli
: Iya mas, masa masukin ke palstik sendiri nggak bisa?
Ilham
Pembeli
: Hei bocah. Aku bisa masukin ke plastik sendiri, tapi aku malas.
Ilham
: Emang malas kenapa?
Fadli dan Azkal : Lupis ham.

Permainan bunyi bahasa juga dapat terlihat pada tuturan tersebut. Dalam tuturan tersebut permainan bunyi bahasa terjadi karena adanya perubahan konsonan /p/ pada kata lupis kemudian dipermainkan dengan konsonan /k/ pada kata lukis. Konteks tuturan tersebut terjadi ketika Ilham mengejek seorang pembeli. Pembeli tersebut mengibaratkan bahwa dirinya raja sehingga ia bisa meminta kepada pedagang untuk menuruti perintahnya seperti misalnya memintanya untuk memasukkan kue ke dalam plastik nya. Ilham pun mengubah makna raja yang disampaikan oleh pembeli dengan raja seorang pemimpin kemudian menyindir pembeli tersebut sebagai raja yang pergi ke pasar untuk membeli kue lupis dan memelesetkan kata lupis menjadi lukis. Adanya permainan bunyi bahasa yang menimbulkan humor ini bertujuan untuk memberikan pelajaran kepada pembeli bahwa selagi masih bisa memasukkan barang ke dalam plastik, tidak perlu untuk meminta bantuan kepada pedagang dan menganggap 
dirinya sebagai raja yang harus dituruti perintahnya.

\section{Permainan Kata}

Permainan kata juga dapat dikatakan sebagai bentuk plesetan bahasa. Permainan kata dilakukan dengan cara mengecoh baik yang dilakukan penutur maupun mitra tutur melalui proses penggabungan kata, yang akhirnya menimbulkan makna baru. Berbeda dengan permainan bunyi bahasa yang dilakukan secara tidak disengaja, pada permainan kata dilakukan oleh penutur secara disengaja. Permainan kata dilakukan dengan membolak-balikkan kata yang memiliki kemiripan. Beberapa temuan data yang menunjukkan strategi penciptaan humor dalam permainan kata dapat dilihat dalam beberapa kutipan data berikut ini.

Data 10

Ilham : Begini saja main tebak-tebakan buah, yang bisa jawab boleh gigit Apel.

Azkal fadli : Setuju

Fadli : Aku dulu ya. Sebutkan 10 buah yang berakhiran huruf "k"

Azkal : Jeruk, salak, kesemek, sirsak terus apa lagi ya?

Fadli : Wah belum 10 Baru empat.

Ilahm : Aku tahu

Fadli : Apa ham?

Ilham : Jambu busuk, jeruk busuk, anggur busuk, dll.

Tuturan humor tersebut terjadi ketika Fadli membawa buah Apel pemberian pak Samintul. Azkal ingin membagi buah Apel tersebut menjadi tiga bagian agar Fadli dan Ilham juga dapat merasakannya. Namun sayangnya di antara mereka bertiga tidak ada yang membawa pisau. Akhirnya Ilham menyarankan untuk bermain tebak-tebakan, dan siapa yang bisa menjawab boleh mengigit Apel. Pertanyaan datang dari Fadli dengan memberikan tebakan kepada Ilham dan Azkal untuk menyebutkan 10 buah yang berakhiran huruf K. Permainan kata pun diciptakan oleh Ilham dengan menjawab sepuluh buah yang berakhiran huruf K. Buah-buahan tersebut seperti buah pada umumnya hanya saja diakhiran kata ditambahkan kata busuk seperti jeruk busuk, jambu busuk, anggur busuk, dll, atau dapat dipahami bahwa ilham menyebutkan jenis-jenis buah tetapi ditambahi dengan kata busuk disetiap nama buah yang disebutkannya. Jawaban dari Ilham tersebut dibenarkan oleh Fadli dan diperbolehkan untuk memakan buah Apel sehingga tuturan Ilham tersebut memunculkan humor pada aspek permainan kata.

Data 11

Bu guru : Betul. Nah sekarang negara Indonesia adalah negara kesatuan yang berbentuk apa?

Ilham : Republik bu,.

Bu guru : Betul, Ilham. Nah, negara republik dipimpin oleh seorang?

Ilham : Seorang saja, Bu.

Bu guru : Loh kok seorang saja, Ham? Seorang presiden, Ilham.

Permainan kata untuk menciptakan humor dapat dilihat seperti pada dialog tersebut. Dalam dialog tersebut konteks tuturan terjadi ketika Bu guru menanya- 
kan kepada murid-murid kelas tentang sebutan bagi pemimpin negara yang berbentuk presiden. Kata seorang yang disampaikan oleh Bu guru untuk memancing lawan tutur tersebut kemudian dimainkan oleh Ilham dengan menambahkan kata saja sehingga menjadi seorang saja. Meskipun berulangkali bu guru menjelaskan bahwa bentuk kepala pemimpin Negara republic adalah presiden, Ilham tetap berikeras menjawab seorang saja sebab jabatan presiden hanya diduduki oleh satu orang.

Data 12

Bu guru : Sendi yang hanya bisa bergerak satu barah disebut sendi apa, Ilham? Tau gak Ham?

Ilham : Sendi...rian, Bu. Kalau gak sendirian bisa kemana-mana. Seperti aku. Main bareng Azkal, main bareng Fadli. Gak cuma satu arah.

Sama dengan kutipan dialog sebelumnya, pada kutipan tersebut juga terjadi permainan kata untuk menciptakan humor. Hal ini dapat dilihat ketika Bu guru menanyakan tentang sendi dalam tubuh manusia yang hanya bergerak satu arah. Namun sayangnya jawaban yang disampaikan oleh Ilham dengan memanfaatkan permainan kata berhasil menciptakan humor. Hal tersebut dapat dilihat pada kata sendi yang disampaikan oleh Bu guru yang selanjutnya dipelesetkan menjadi sendirian oleh Ilham. Tuturan tersebut dapat diartikan sebagai penciptaan humor melalui permainan kata, sebab antara kata sendi dan sendirian memiliki makna yang berbeda.

\section{Ridicule (Membuat Orang Bodoh)}

Dari adanya ejekan dan teknik mengecoh yang diucapkan oleh penutur, ternyata juga menimbulkan teknik humor dengan membuat lawan tutur seolah bodoh. Hal ini dapat dilihat dari sikap lawan tutur yang terlihat bingung dan mengalah dalam menerima ejekan yang diucapkan oleh penutur. Beberapa kutipan data yang menunjukkan stategi penciptaan humor pada tayangan Bocah $\mathrm{Ngapa(K)} \mathrm{Ya}$ melalui proses membuat orang bodoh dapat dilihat dalam kutipan berikut.

Data 13

Bu guru : Ilham. Perjanjian renville ditandatangani di mana?

Ilham : Perjanjian renville ditandatangani di pojok kanan bawah surat, $\mathrm{Bu}$. Nah, seperti ini. Belum yang tanda tangan tersebut

Konteks Tuturan tersebut terjadi ketika Bu guru menanyakan kepada Ilham letak perjanjian renville ditandatangani. Dalam tuturan tersebut tampak jelas terjadi ketidaksantunan berbahasa yang dilakukan oleh Ilham sehingga menimbulkan bentuk humor dengan teknik membuat orang bodoh. Hal ini terlihat pada tuturan Ilham yang mengecoh jawaban guru, dengan menjawab bahwa perjanjian renville ditandatangani di pojok kanan bawah. Padahal jawaban yang diinginkan oleh Bu guru adalah tempat tersebut yaitu kapal perang Amerika Serikat USS Renville, di Pelabuhan Tanjung Priok, Jakarta. Namun Ilham ingin memunculkan humor, sehingga ia pun menjawab dengan jawaban yang demikian.

Data 14

Bu guru : Betul. Sekarang Ilham, kamu tau mamalia?

Ilham : : Tau, Bu. Mamalia itu Bu Tarma. 


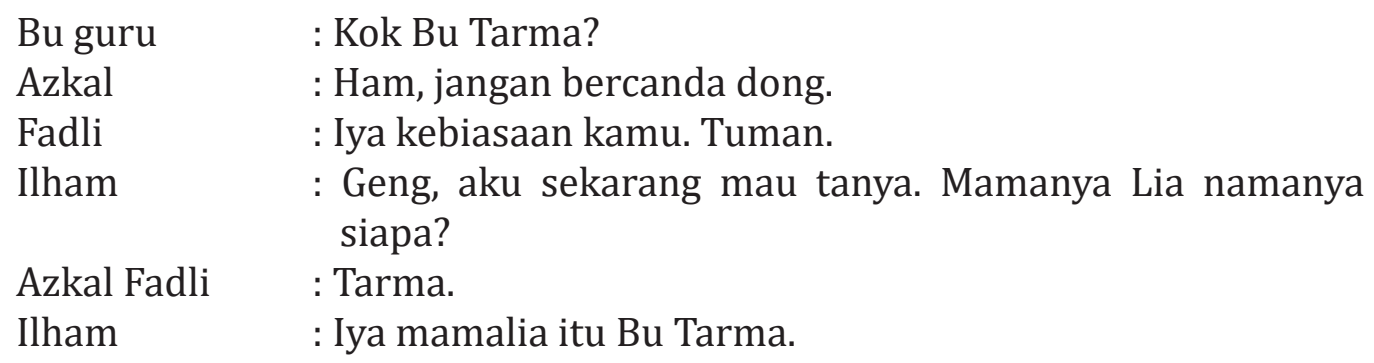

Tuturan tersebut juga memanfaatkan teknik mengecoh lawan tutur untuk menciptakan humor. Hal ini terlihat dari tuturan Ilham yang mengecoh Bu guru dengan mengatakan bahwa mamalia adalah Bu Tarma. Konteks Tuturan tersebut terjadi karena Bu guru meminta Ilham untuk menyebutkan jenis hewan mamalia. Mamalia merupakan salah satu jenis hewan yang menyusui. Bu guru meminta Ilham untuk menyebutkan jenis-jenis hewan mamalia. Tetapi oleh Ilham, kata mamalia dipelesetkan menjadi mama Lia (nama orang), dan menjawab bahwa mamlia adalah Bu Tarma, sehingga tingkah laku Ilham tersebut menimbulkan bentuk humor karena baik Azkal dan Bu Guru mengalah dengan jawaban Ilham. Data 15

Fadli : Lah, kenapa ham? Kok gak boleh tambal di sana?

Ilham : Soalnya lama, fad. Yakin. Lama banget.

Bu guru : Kok lama? Kenapa, jam? Apa rame yang tambal di sana?

Ilham : Gak, Bu. Sudahlah pokoknya jangan tambal di sana.

Azkal : Iya kenapa, ham? Yang jelaslah.

Ilham : Memang gak pernah lihat? Kan ada tulisannya. Tambal ban 24 jam.

Azkal : Iya lihat lha terus kenapa?

Ilham : Tambal ban masa 24 jam? 24 jam itu lama banget. Paling tambal ban cuma 15 menit.

Tuturan tersebut juga termasuk bentuk humor melalui teknik mengecoh lawan tutur. Dalam dialog tersebut terlihat bahwa Ilham mengecoh lawan tutur dengan mengubah maksud 24 jam. Dalam tulisan tambal ban 24 jam memiliki maksud untuk melayani tambal ban selama sehari penuh. Tetapi oleh Ilham 24 jam diubah maknanya dengan diartikan bahwa tambal ban memiliki rentang waktu selama sehari penuh. Tuturan mengecoh yang dilakukan oleh Ilham tersebut menimbulkan humor.

\section{Repartee (Mengejek)}

Mengejek sebenarnya menjadi bentuk pelanggaran prinsip kesantunan berbahasa. Sebab dalam teknik ini lawan tutur seakan dirugikan oleh perkataan yang diucapkan oleh penutur. Dengan kata lain tuturan yang disampaikan oleh penutur seakan merugikan bagi lawan tutur sebab bersifat menjatuhkan. Bentuk humor melalui ejekan biasanya berhubungan dengan fisik, status sosial ataupun pengalaman hidup, dll. Dalam tuturan humor Bocah Ngapak (Ya), tidak ditemukan strategi penciptaan humor dengan teknik mengolok yang terlalu merendahkan orang lain hingga berlebihan. Hal ini dapat dilihat dalam beberapa kutipan berikut. 
Data 16

Pak guru : Terus omnivora contohnya apa?

Ilham : Azkal

Azkal : Kenapa aku?

Ilahm : Lha iya kan aku suka lihat kamu makan, daging, telur, tempe, tahu, segalanya dimakan.

Tuturan tersebut terjadi ketika Pak guru memberikan pertanyaan kepada Ilham mengenai contoh dari hewan omnivora. Namun sayangnya Ilham menjawab bahwa hewan omnivore tersebut adalah Azkal. Tuturan humor tersebut termasuk dalam jenis humor merendahkan orang lain. Hal ini terlihat pada tuturan Ilham yang mengatakan bahwa Azkal termasuk jenis hewan omnivora atau hewan pemakan segalanya. Padahal, sudah jelas bahwa Azkal adalah manusia bahkan temannya bermain sehari-hari. Namun karena dia memiliki hobi makan segala hal yang disukainya dan membuat perutnya gendut, Ilham menjadikan hal tersebut sebagai bahan tertawaan dan memunculkan bentuk humor.

Data 17

Azkal : Aman gak fals.

Ilham : Suara mu sendiri yang fals

Azkal : Ahhh, apa iya? Sebentar di tes ya.

Tuturan tersebut terjadi ketika Ilham, Fadli dan Azkal sedang latihan vokal. Dalam tuturan tersebut Azkal selaku guru vokal mengajarkan Ilham dan Fadli tentang tangga nada. Azkal meminta Fadli untuk mengucapkan tangga nada. Setelah Fadli selesai, Azkal memuji bahwa tangga nada yang baru saja diucapkan oleh Fadli aman dalam artian tidak ada yang fals. Tuturan humor terjadi ketika Ilham menegaskan bahwa suara yang fals adalah suara Azkal. Dalam hal ini jelas tidak mungkin jika suara azkal fals. Pasalnya dia selaku guru vokal maka sudah tentu suaranya bagus dan tidak mungkin jika memiliki suara yang fals. Maka tuturan merendahkan yang dilontarkan oleh Ilham tersebut menimbulkan tawa bagi penonton.

Data 18

$\begin{array}{ll}\text { Azkal } & \text { : Ham, mau kemana? Kok sama Mbak Tyas? } \\ \text { Ilham } & \text { : Mau ikut mainan Az. } \\ \text { Fadli } & \text { : Ini mainan anak laki-laki ham. Masa Mbak Tyas mau ikut. } \\ \text { Ilah } & \text { : Aku yang mau ikut fad } \\ \text { Fadli } & \text { : Lha Mbak Tyas mau ngapain? } \\ \text { Tyas } & \text { : Aku mau beli pemutih di warung tapi warungnya tutup. } \\ \text { Fadli } & \text { : Pemutih wajah mbak? } \\ \text { Ilham } & \text { : Kalau bicara pemutih jangan didekat Azkal! }\end{array}$

Konteks tuturan tersebut terjadi ketika Fadli dan Azkal sedang berbincang kemudian Ilham dan Mbak Tyas datang. Mereka baru saja pergi dari warung membeli pemutih pakaian untuk membersihkan pakaian Mbak Tyas yang terkena noda. Tuturan tersebut juga termasuk humor merendahkan orang lain. Hal ini terlihat pada tuturan yang disampaikan oleh Ilham dengan meminta agar Fadli tidak membicarakan mengenai pemutih di dekat Azkal. Hal ini pasti akan membuat Azkal merasa tersindir dan marah karena memiliki kulit hitam. Tuturan hu- 
mor tersebut diciptakan oleh Ilham dengan tujuan untuk menyindir Azkal yang memiliki kulit warna hitam.

\section{SIMPULAN}

Humor merupakan salah satu hal lucu yang bertujuan untuk menghibur audience atau penonton untuk tertawa. Humor dapat digunakan untuk melepas penat atau sekadar menghibur diri setelah beraktivitas. Humor tidak akan terbentuk jika hanya melalui gerak badan atau tubuh semata. Tetapi, sarana bahasa yang yang digunakan untuk berkomunikasi juga turut mendukung keberhasilan humor sehingga dapat membangkitkan tawa audien. Berdasarkan hasil uraian di atas maka dapat disimpulkan bahwa tayangan humor Bocah $\mathrm{Ngapa(K)} \mathrm{Ya} \mathrm{sengaja}$ diproduksi yang ditujukkan terutama bagi anak-anak. hal ini dapat dilihat dari para pemian yang notabenenya masih di bawah usia remaja, tema yang diangkat sangat ringan dan dikemas dengan gaya kekinian. Selain itu penciptaan bahasa humor pada tayangan Bocah $\operatorname{Ngapa(K)~Yadapat~dilihat~melalui~ironi,~}$ misunderstanding, permainan bunyi, perminan kata, redicule, dan repartee. Beberapa penciptaan humor melalui bahasa yang tidak ditemukan dalam humor Bocah Ngapa(K) Ya di antaranya yaitu bombast, satire, sarcasm, sexual, dan outwitting. Beberapa strategi penciptaan humor melalui bahasa yang tidak ditemukan tersebut disebabkan karena tayangan humor tersebut diperankan oleh anak-anak. Dari hal tersebut beberapa humor yang seperti berhubungan dengan seksualitas, sarkasme, membuat orang bodoh, berbicara muluk-muluk dan menjatuhkan orang lain sengaja tidak ditampilkan karena diusia yang masih kecil belum pantas untuk berbicara yang demikian.

Daftar Pustaka

Aisyah, Z. I. (2018). Bahasa Humor Dalam Tuturan Ketut Yoga Yudistira Pengisi Suara Channel Youtube Kok Bisa? Bapala, 5(2), 1-11.

Anastasya, S. (1AD). Teknik-Teknik Humor dalam Program Komedi di Televisi Swasta Nasional Indonesia. JURNAL E-KOMUNIKASI, 1(2013), 1-11.

Arnita, M., Supriyadi, \& Ansori. (2019). Tuturan Humor dalam Acara Tayangan Opera Van Java di Televisi Trans 7. Logat, 7(1), 29-47.

Budiyanto, D. (2009). Penyimpangan Implikatur Percakapan dalam HumorHumor Gus Dur. Litera, 8(2), 105-117.

Hasanuddin, P. U. (2019). Peran Humor dalam Modal Sosial. Jispo, 9(2), 382-393.

Hilmi, M. (2018). Humor dalam Pesan Dakwah. Jurnal Ilmu Dakwah, 38(1), 87-110.

Jatiyasa, I. W. (2019). Implementasi Humor dalam Pembelajaran di Stkip Agama Hindu Amlapura. Jurnal Mitra Pendidikan (JMP Online), 3(1), 65-80.

Rohmadi, M. (2010). Strategi Penclptaan Humor dengan Pemanfaatan AspekAspek Kebahasaan. Humaniora, 22(3), 285-298.

Saddhono, K. (2009). Analisis Wacana. Surakarta: UNS press.

Suaib, E., Zainal, R., \& Liliana, M. (2019). Tipe dan Fungsi Humor dalam Acara Indonesia Lawak Klub di Trans 7. Madah: Jurnal Bahasa Dan Sastra, 10(1), 123-136.

Sukardi, M. I., Sumarlam, \& Sri, M. (2018). Penyimpangan Makna dengan Homonimi dalam Wacana Meme (Kajian Semantik). Lingua, 13(1), 23-34. 
Ferdian Achsani

Utami, I. I. (2018). Strategi Humor pada Acara Stand Up Comedy. Adabiyyāt: Jurnal Bahasa Dan Sastra, II(2), 219-245.

Widyaningsih, R. (2014). Bahasa Ngapak dan Mentalitas Orang Banyumas: Tinjauan dari Perspektif Filsafat Bahasa Hans-Georg Gadamer. Jurnal Ultima Humaniora, 2(2), 186-200. 